\title{
Simplified five-level voltage source inverter with level-phase- shifted carriers based modulation technique
}

\author{
Suroso $^{1}$, Daru Tri Nugroho ${ }^{2}$, Abdullah Nur Azis ${ }^{3}$, Toshihiko Noguchi ${ }^{4}$ \\ ${ }^{1,2,3}$ Electrical Engineering Department, Jenderal Soedirman University, Indonesia \\ ${ }^{4}$ Graduate School of Engineering, Shizuoka University, Japan
}

\section{Article Info \\ Article history: \\ Received Jul 11, 2018 \\ Revised Sep 12, 2018 \\ Accepted Sep 26, 2018}

\section{Keywords:}

Harmonics

Modulation

Power inverter

\begin{abstract}
A simplified circuit topology of the five-level inverter for DC-AC power conversion with non-insulated DC power sources along with reduced switching device count is introduced and discussed in this research paper. The inverter circuit is based on the three-level H-bridge inverter configuration. The developed five-level PWM inverter needs five controlled power switches and four isolated gate drive circuits. Furthermore, the proposed topology does not require bidirectional power semiconductor controlled switches, hence a conventional discrete power MOSFETs or IGBTs can be used to build the inverter circuits. To achieve a better quality AC output voltage, the level-phase-shifted carriers based sinusoidal pulse width modulation was applied to create a five-level PWM voltage waveform. The developed inverter circuit was examined by utilizing computer simulation with Power PSIM software. The basic principle operation of the inverter circuit was verified experimentally in laboratory applying two noninsulated DC input voltage sources as the inputs of the inverter's prototype circuit. Some analysis of inverter's output waveforms are provided and discussed.
\end{abstract}

Copyright (C) 2019 Institute of Advanced Engineering and Science. All rights reserved.

Corresponding Author:

Suroso,

Electrical Engineering Department, Jenderal Soedirman University,

Jl. Mayjen Sungkono km.5, Purbalingga, Jawa Tengah, Indonesia.

Email: suroso.te.unsoed@gmail.com

\section{INTRODUCTION}

The demand of high power and high quality power inverters for many utilizations as industrial motor drives and renewable energy conversions encourages the researchers to develop new converter topologies such as multilevel power inverters. Contrast to the traditional two-level power inverter, the multilevel power inverters possess some merits such as their potential to yield a higher output power, reduced voltage change (dv/dt), decreased gradient current change (di/dt), and preferable characteristic of AC voltage waveforms effecting in less electromagnetic noise. The multilevel power inverter can also reduce the output filter size by enhancing the inverter's level count [1-5].

The definition of multilevel power inverter circuits includes a three-level power inverter, and the inverters with higher level number. To date, a lot of inverter topologies especially voltage source inverter (VSI) circuits have been developed. Basically, there are four major topologies of multilevel VSI topologies have been presented [6]. They are the cascaded H-bridges multilevel VSI with disjunct DC power sources, the neutral clamped multilevel VSI, the flying capacitors VSI and the hybrid topology of multilevel VSI [7-12].

The topology of cascaded full-bridge power inverter with cloistered DC power sources has a great merit with its modularity. Even thought, it has disadvantage such as the need of many disjunct DC voltage power sources, and the large number of controlled power switches. The more the controlled switches, 
the more count of isolated driving circuits are requisite. The second topology i.e. the diode clamped multilevel VSI has been widely applied in modern AC motor drive application. The topology of flying capacitor VSI is another alternative. However, the number of capacitors required in this inverter circuits will cause another challenge such as the intermediate voltage control of the capacitor voltages. The fourth topology is the hybrid multilevel VSI. Basically, the hybrid topology is the topology of multilevel inverter developed to reduce some shortfalls in the three topologies of multilevel inverter circuits previously discussed. Still, the circuit complexity has become another issue of the multilevel power inverter circuits.

Circuit of a hybrid multilevel power inverter created from the $\mathrm{H}$-bridge voltage source inverter and sub-multilevel circuits was discussed in [13]. The sub-multilevel circuit is constructed using capacitor and two bidirectional controlled switches. Another circuit topology of multilevel VSI created from a full-bridge inverter and an additional bidirectional active power switch as shown in Figure 1 was presented in [14]. Nevertheles, the additional bidirectional controlled power switches in inverter topologies described in reference [13] and [14] will cause some drawbacks of the inverter. The conventional bidirectional power semiconductor controlled switches constructed by combining two unidirectional powersemiconductor controlled switches or a single controlled power switch with four diodes cause the total inverter power losses go up. Another structure of multilevel inverter circuits built from the three-level cell of H-bridge inverter was provided in [15]. Eight active switches are entailed in this inverter circuit. Circuit structure of a five-level multistring inverter was discussed in [16] and [17]. Two detached DC voltage sources with six active switches are demanded in this inverter circuit. The five-level multistring inverter structure is shown in Figure 2. The large quantity of controlled power switches and the requirement of separated DC voltage power sources will escalate the intrycacy of inverter power circuits. Papers [18] described another multilevel voltage source power inverter constructed by H-bridge VSI and two-level voltage source modules. In this topology, six controlled power switches with five disjunct gate drive power supplies are entailed to operate the switches of inverter.

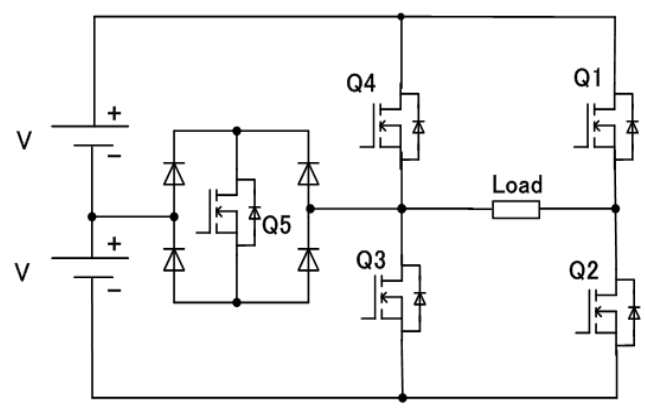

Figure 1. Five-level inverter employing H-bridge VSI and auxiliary bidirectional switch [14]

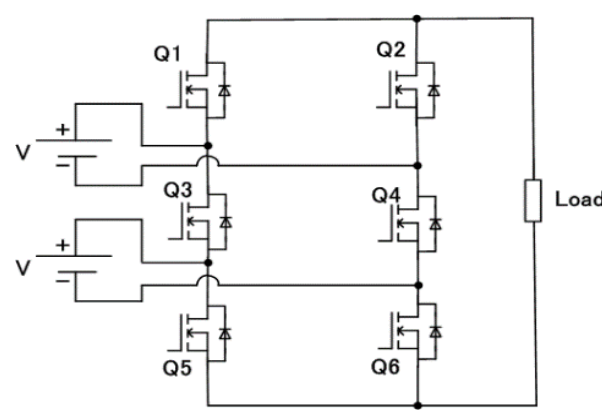

Figure 2. Five-level multistring inverter [16]

\section{RESEARCH METHOD}

In this research paper, a distinct topology of five-level VSI with non insulated DC voltage power sources and reduced switching device count is presented. Furthermore, the developed five-level VSI circuits need only four gate drive circuits for gating signal generation. In the developed inverter topology, the DC input power sources are non-insulated DC sources. Furthermore, all controlled power semiconductor switches are sole directional switches. The five-level VSI circuit was designed and tested through computer simulations utilizing Power PSIM Software. Furthermore, the basic principle operation of the inverter circuit was verified experimentally in laboratory of the inverter's prototype circuit.

\subsection{Proposed Inverter Circuits and Its Basic Operation}

Figure 3 is the new circuit of five-level power inverter. In this new topology, only five active power switches with four isolated gate drive power supplies and a single discrete diode are required. The less the active semiconductor switches, the simpler inverter circuits will be obtained. A low pass filter consists of inductor $\left(\mathrm{L}_{\mathrm{f}}\right)$ and capacitor $\left(\mathrm{C}_{\mathrm{f}}\right)$ is connected to the inverter. Table 1 indicates the switching conditions of the new five level VSI for five level voltage evocation. Moreover, Figure 4 presents the detailed operation modes for five-level PWM voltage waveform $\left(\mathrm{V}_{\mathrm{PWM}}\right)$ evocation, specifically $+2 \mathrm{~V},+\mathrm{V}, 0,-\mathrm{V}$ and $-2 \mathrm{~V}$ output voltage levels. The load voltage waveform get near to a sinusoidal voltage, which is a five-level PWM voltage after filtering by the low pass filter. 


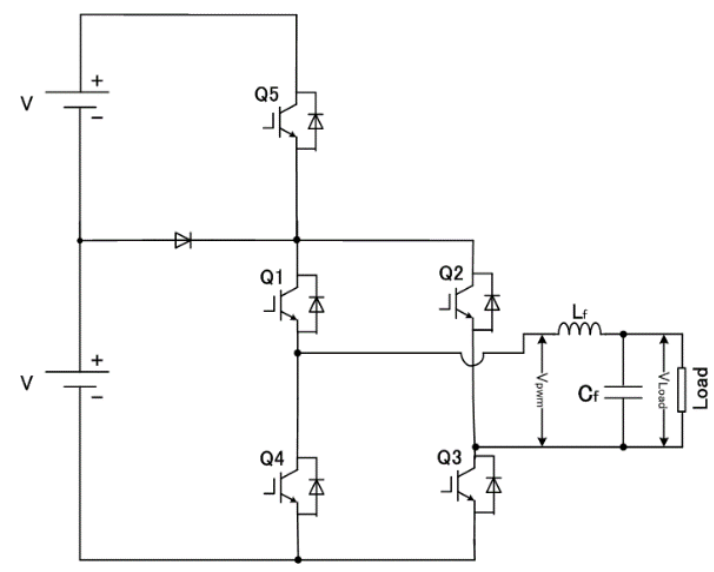

Figure 3. The circuit of proposed five-level VSI

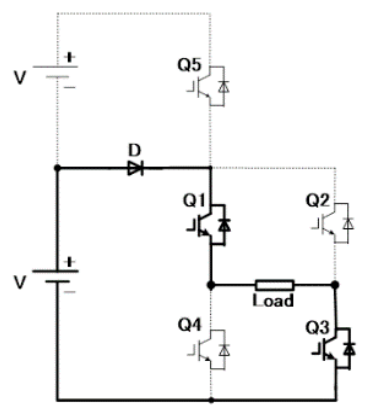

(a) Mode I: +V level voltage

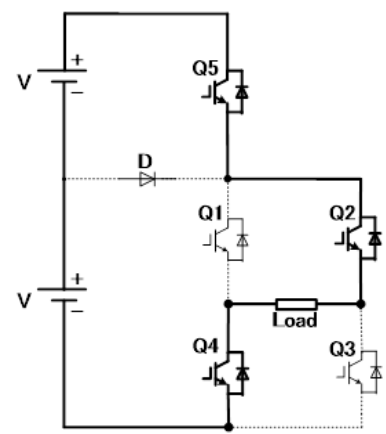

(d) Mode IV: -2V level voltage

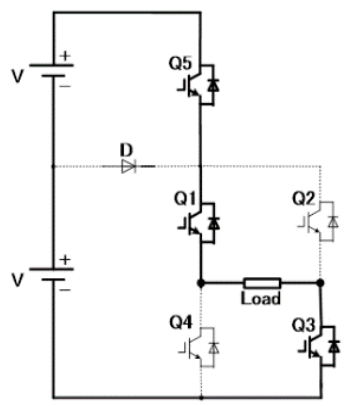

(b) Mode II: $+2 \mathrm{~V}$ level voltage

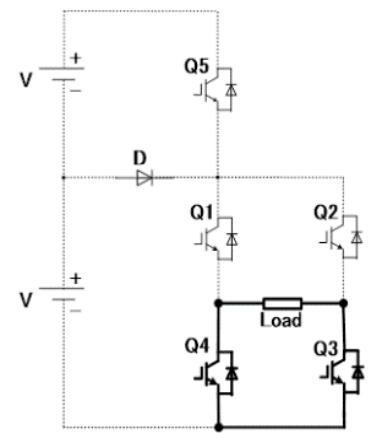

(e) Mode V: 0 level voltage

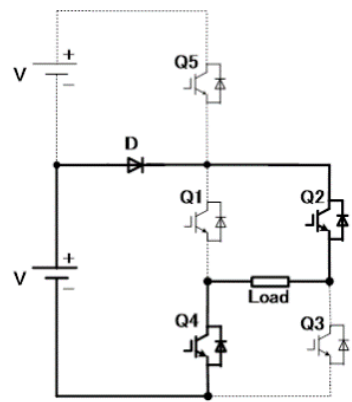

(c) Mode III: -V level voltage

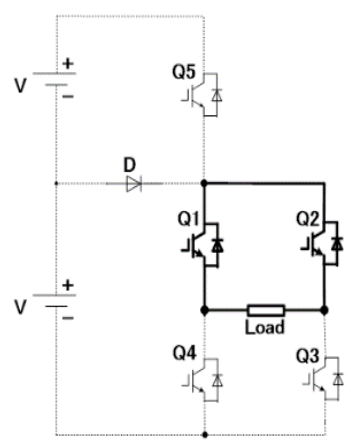

(f) Mode VI: 0 level voltage

Figure 4. Operation modes of five-level VSI

Table 1. Switching Conditions of Five-Level VSI

\begin{tabular}{cccccccc}
\hline Operation Modes & $\mathrm{Q}_{1}$ & $\mathrm{Q}_{2}$ & $\mathrm{Q}_{3}$ & $\mathrm{Q}_{4}$ & $\mathrm{Q}_{5}$ & $\mathrm{D}$ & $\mathrm{V}_{\mathrm{PWM}}$ \\
\hline I & 1 & 0 & 1 & 0 & 0 & 1 & $+\mathrm{V}$ \\
II & 1 & 0 & 1 & 0 & 1 & 0 & $+2 \mathrm{~V}$ \\
III & 0 & 1 & 0 & 1 & 0 & 1 & $-\mathrm{V}$ \\
IV & 0 & 1 & 0 & 1 & 1 & 0 & $-2 \mathrm{~V}$ \\
V & 0 & 0 & 1 & 1 & 0 & 0 & 0 \\
VI & 1 & 1 & 0 & 0 & 0 & 0 & 0 \\
\hline
\end{tabular}

\subsection{Inverter's Modulation Technique}

A pure sinusoidal waveform of current and voltage are ideal shape for almost all AC power load. Nevertheless, in real condition many factors affect the real shape of curret and voltage. Because of voltage drop in the circuits and voltage ripple of the DC input voltage source, harmonic will appear in the AC voltage and current waveforms of a power inverter. In many inverter circuits some modulation strategies are applied 
to achieve lower distortion of current and voltage $[19,20]$. Furthermore, power filter circuits are also added to filter switching harmonics in order to obtain a closer sinusoidal waveforms. In this research, the level and phase shifted carriers based modulation was implemented for the driving signals generation of inverter's switches as displayed in Figure 5. Two carrier signals with an identical frequency but have contrary phase and different offset level were used together with a sinusoidal modulating signal as shown the figure. The basic frequency component of AC current and voltage waveforms is regulated by the sinusoidal modulating signal as the modulator waveform. Switching rapidity of the inverter's power semiconductor switches is the same with the frequency of triangular carrier signals [21, 22]. Gating signals of inverter are produced by the PWM generator controlling the ON/OFF condition of inverter's power semiconductor switches to output the desired five-level voltage shape. The gate drive circuits work as interface and isolation between the high power and control circuits.

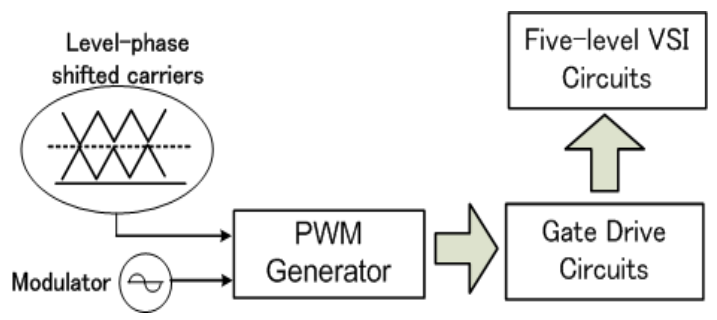

Figure 5. Modulation technique of the five-level VSI

\section{RESULTS AND ANALYSIS}

\subsection{Computer Simulation Test Results}

Computer simulations experiments were performed to verify and to prove the basic principle works of the developed five-level VSI circuits. Parameters of simulation test were indicated in Table 2. A five-level VSI circuit as displayed in Figure 3 was examined. A low-pass filter circuit with inductor $\mathrm{L}_{\mathrm{f}}=1 \mathrm{mH}$ and capacitor $\mathrm{C}_{\mathrm{f}}=5 \mu \mathrm{F}$ was used. The five-level VSI circuit was connected with a resistive and inductive power load, i.e. power resistor $10 \Omega$, and power inductor $1 \mathrm{mH}$. The switching operation frequency of controlled power semiconductor switches was designed as $21 \mathrm{kHz}$ to minimize the audible noise and to push the switching harmonics into higher frequency orders. The output voltage fundamental frequency was $50 \mathrm{~Hz}$. Two non-isolated $12 \mathrm{~V}$ DC input voltage sources were used as the inverter's inputs.

Figure 6 indicates test results of computer simulation presenting the output voltage waveforms created by the five-level VSI circuit. A five-level voltage waveform has been confirmed. Furthermore, a sinusoidal voltage was applied to the power load after filtering by a low-pass filter. Figure 7 is harmonic profile of the generated five-level voltage waveform for frequency range up to $50 \mathrm{kHz}$. Switching harmonic components and its sidebands appeared around frequency $21 \mathrm{kHz}$ and its multiples. Figure 8 presents the low harmonic orders of the produced five-level output voltage. The amplitudes of all low harmonic orders were less than $1 \%$. Furthermore, Figure 9 displays a current waveform flowing thru the power load, power switch $\mathrm{Q}_{5}$ and power diode D of inverter circuits. A sinusoidal current, ILoad, flowed supplying electric power to the load circuit. The currents flowing via the switch $\mathrm{Q}_{5}$ and diode $\mathrm{D}$ were the PWM currents with frequency $21 \mathrm{kHz}$.

Table 2. Test Parameters

\begin{tabular}{clc}
\hline No. & Parameters & Values \\
\hline 1 & DC input power source voltages & $12 \mathrm{~V}$ \\
2 & Switching operation frequency & $21 \mathrm{kHz}$ \\
3 & Inductor power filters, $\mathrm{L}_{\mathrm{f}}$ & $1 \mathrm{mH}$ \\
4 & Capacitor power filter, $\mathrm{C}_{\mathrm{f}}$ & $5 \mu \mathrm{F}$ \\
5 & Power load & $R=10 \Omega, L=1 \mathrm{mH}$ \\
6 & Fundamental output frequency & $50 \mathrm{~Hz}$ \\
\hline
\end{tabular}



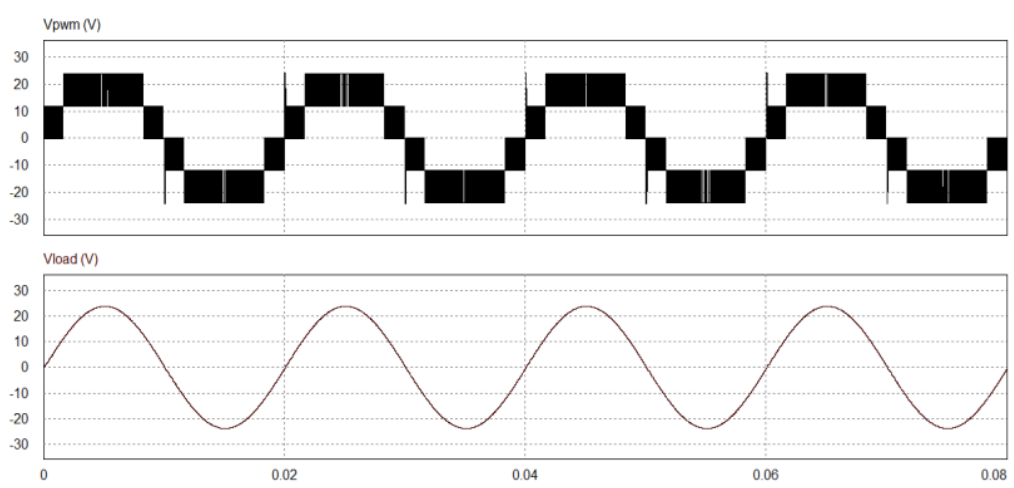

Figure 6. Five-level PWM AC voltage $\left(\mathrm{V}_{\mathrm{pwm}}\right)$, and load voltage $\left(\mathrm{V}_{\text {Load }}\right)$ waveforms

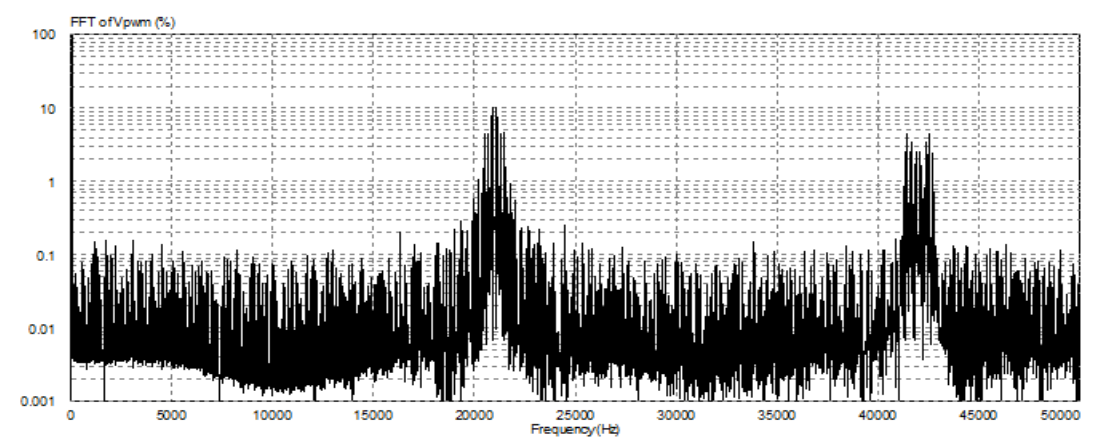

Figure 7. Harmonic profile of five-level voltage with the switching harmonics constituents

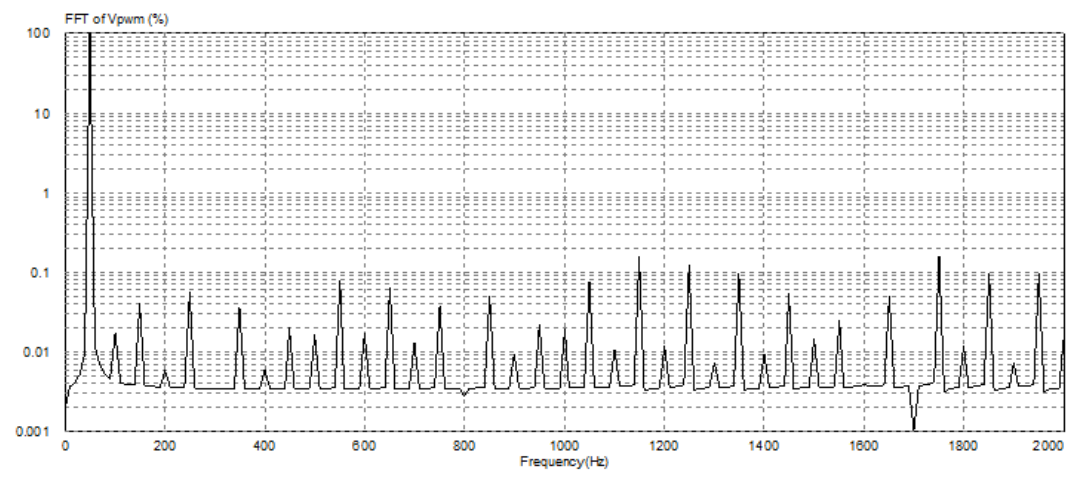

Figure 8. Profile of the low harmonic components

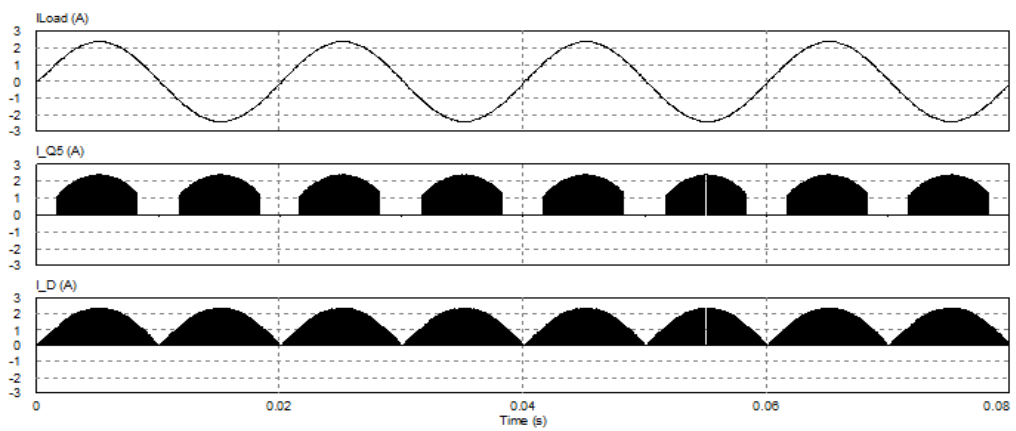

Figure 9. Waveforms of currents flowing thru the load, switch $\mathrm{Q}_{5}$ and diode $\mathrm{D}$ 


\subsection{Laboratory Prototype Test Results}

In order to examine the five-level VSI circuits experimentally, a five-level inverter prototype was made using five power MOSFETs FK30SM-6, and a single power diode VS-30ETH06PBF. The level-phase shifted carriers based PWM technique was applied. The DC input power sources were acquired from the two adjustable DC voltage sources connected in series. Figure 10 shows the laboratory experimental set-up of the prototype five-level inverter.

Figure 11 presents the firing signals of the MOSFETs switches $\mathrm{Q}_{2}$ and $\mathrm{Q}_{3}$ obtained from the $\mathrm{PWM}$ circuits after passing the driver IC TLP 250 . Figure 12 is the gating signals of switches $\mathrm{Q}_{1}$ and $\mathrm{Q}_{4}$. The gating signal of MOSFET switch $\mathrm{Q}_{5}$ is presented in Figure 13. These signals were used to control the operation of five-level inverter circuits to generate a five-level PWM voltage waveform.

Figure 14 shows the experimental waveform of a five-level PWM output voltage generated by the inverter when the modulation index 0.9. A five level PWM AC voltage was experimentally confirmed. The harmonic spectrum of this waveform is shown in Figure 15. The switching harmonics component and its sidebands appeared around the frequency $21 \mathrm{kHz}$ and its multiples. This frequency is the switching frequency of the power MOSFETs used in inverter. Furthermore, the measured load voltage waveform is shown in Figure 16. A sinusoidal voltage was obtained after filtering the five-level PWM voltage waveform. The laboratory test results agreed with the computer simulations.

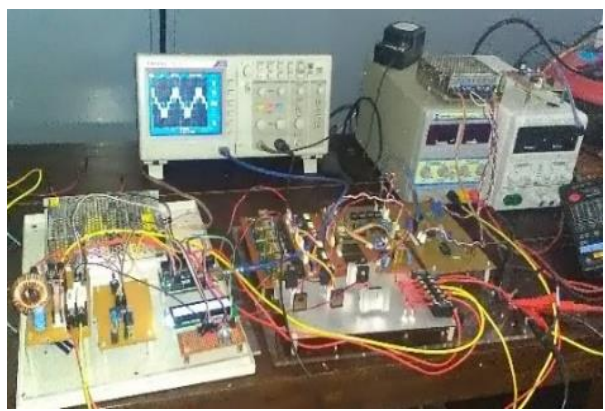

Figure 10. Experimental set-up of the laboratory prototype

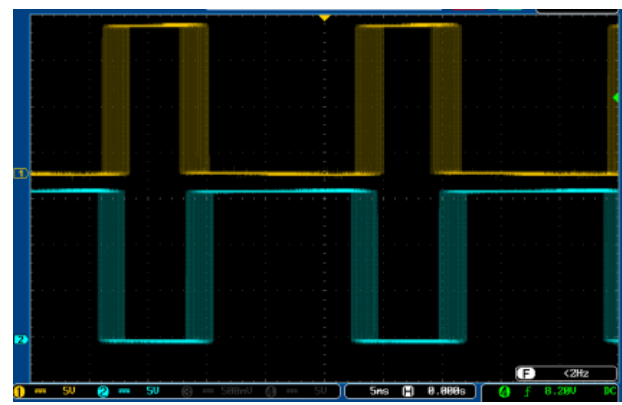

Figure 12. Gating signals of switches $\mathrm{Q}_{1}$ and $\mathrm{Q}_{4}$

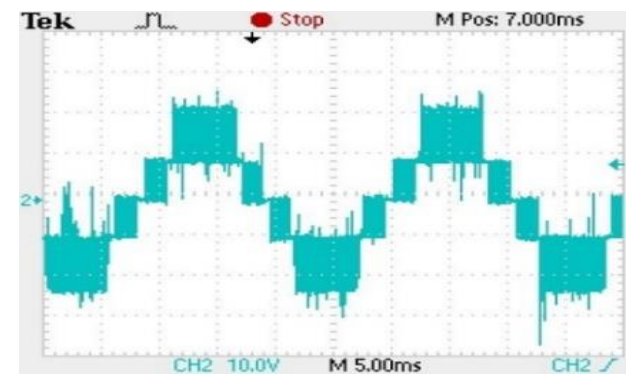

Figure 14. Experimental test result of five-level voltage

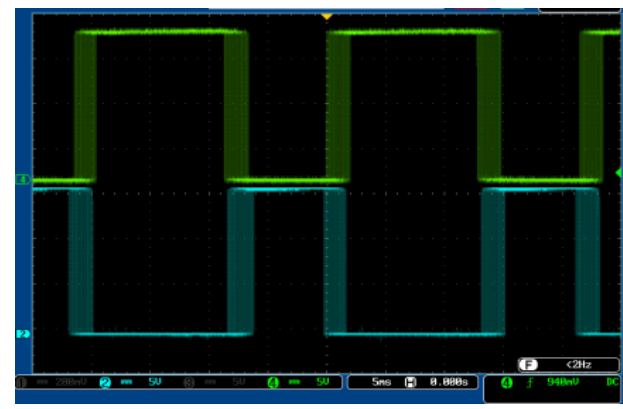

Figure 11. Gating signals of switches $\mathrm{Q}_{2}$ and $\mathrm{Q}_{3}$

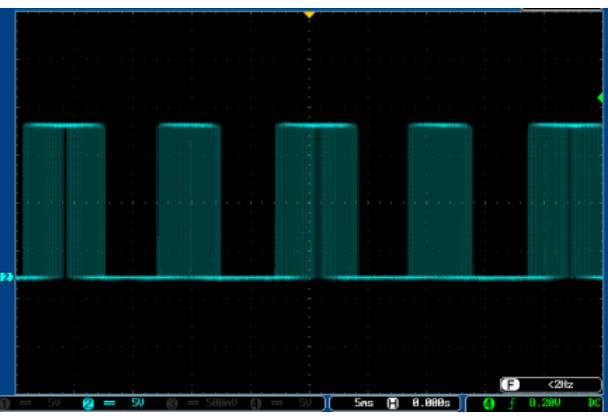

Figure 13. Gating signal of switch $\mathrm{Q}_{5}$

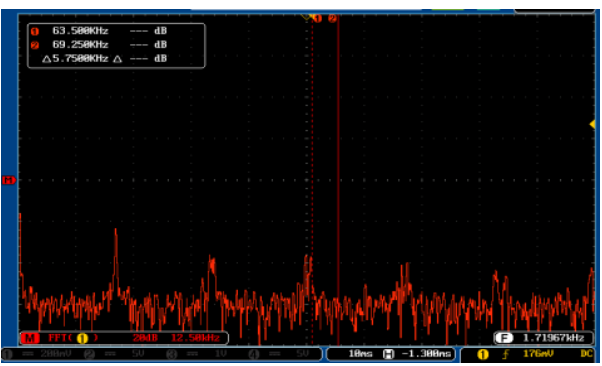

Figure 15. Harmonic profile of five-level voltage 


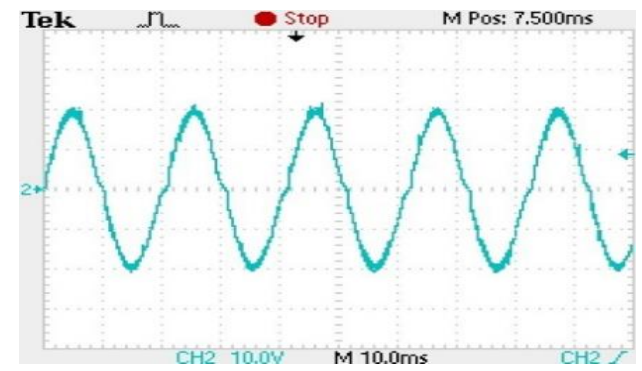

Figure 16. Experimental test result of the load voltage waveform

\section{CONCLUSION}

A simplified circuit structure of five-level voltage source inverter is being developed. Principle works of the inverter circuits have been presented and discussed. The presented five-level voltage source inverter needs five controlled power switches and a single discrete diode only, to generate a five-level PWM voltage waveform with non insulated dc power sources. Nethermost quantity of controlled power semiconductor switches needed to create this five-level VSI circuit is the main feature of this power inverter. Some data obtained by using computer simulations and laboratory prototype test have confirmed that the developed inverter circuits worked producing a five-level output voltage waveform. Using the installed low pass filter, this PWM waveform was filtered become a sinusoidal voltage with lower distortion.

\section{REFERENCES}

[1] M. Malinowski, K. Gopakumar, J. Rodriguez, and M. A. Pérez, "A survey on cascaded multilevel inverters," IEEE Transactions on Industrial Electronics, vol. 57, pp. 2197-2206, 2010.

[2] J. Lai and F. Z. Peng, "Multilevel converter-a new breed of power converters," IEEE Transactions on Industry Applications, vol. 32, pp. 509-517, 1996.

[3] G. Ceglia, V. Guzman, C. Sanchez, F. Ibanez, J. Walter and M.I. Gimenez, "A New simplified multilevel inverter topology for DC-AC conversion," IEEE Transactions on Power Electronics, vol. 21, pp. 1311 - 1319, 2006.

[4] Suroso, and T. Noguchi, "A Multilevel Voltage-Source Inverter using H-Bridge and Two-Level Power Modules with a Single Power Source," IEEE International Conference on Power Electronics and Drive System (PEDS), pp. 262-266, 2011.

[5] M. Narimani, B. Wu and N. R. Zargari, “A Novel Five-Level Voltage Source Inverter with Sinusoidal Pulse Width Modulator for Medium-Voltage Applications," IEEE Transactions on Power Electronics, vol. 31, pp. 1959-1967, 2016.

[6] J. Rodiguez, J. S. Lai and F. Z. Peng, "Multilevel inverter: a survey of topologies, controls, and application," IEEE Transactions on Industrial Electronics, vol. 49, pp. 724-738, 2002.

[7] M. F. Escalante, J. Vannier, and A. Arzandé, "Flying Capacitor Multilevel Inverters and DTC Motor Drive Applications," IEEE Transactions on Industrial Electronics, vol. 49, pp. 809-815, 2002.

[8] M. M. Renge and H. M. Suryawanshi, "Five-Level Diode Clamped Inverter to Eliminate Common Mode Voltage and Reduce dv/dt in Medium Voltage Rating Induction Motor Drives," IEEE Transactions on Power Electronics, vol. 23, pp. 1598-1607, 2008.

[9] Z. Du, B. Ozpineci, L. M. Tolbert and J. N. Chiason, "DC-AC cascades H-bridge multilevel boost inverter with no inductors for electric/hybrid electric vehicle applications," IEEE Transactions on Industry Application, vol. 45, pp. 963-970, 2009.

[10] A. Nami, F. Zare, A. Ghosh, and F. Blaabjerg, "A Hybrid Cascade Converter Topology with Series-Connected Symmetrical and Asymmetrical Diode-Clamped H-Bridge Cells," IEEE Transactions on Power Electronics, vol. 26, pp. 51-65, 2011.

[11] K. Crorzine and Y. Familiant, "A new cascaded multilevel H-bridge Drive," IEEE Transactions on Power Electronics, vol. 17, pp. 125-131, 2002

[12] H. Miranda, V. Cardenas, G. Espinosa-Perez, and D. Noriega-Pineda, "Multilevel Cascade Inverter with Voltage and Current Output Regulated Using a Passivity - Based Controller", Conference Record of the 2006 IEEE Industry Applications Conference Forty-First IAS Annual Meeting, pp. 974-981, 2006.

[13] E. Babaei, "A cascade multilevel converter topology with reduced number of switches," IEEE Transactions on Power Electronics, vol. 23, pp. 2657-2664, 2008.

[14] G. Ceglia, V. Guzman, C. Sanchez, F. Ibanez, J. Walter and M. I. Gimenez, "A new simplified multilevel inverter topology for DC-AC conversion," IEEE Transactions on Power Electronics, vol. 21, pp. 1311-1319, 2006.

[15] D. R. Caballero, R. Sanhueza, H. Vergara, M. Lopez, M. L. Heldwein and S. A. Mussa, "Cascaded symmetrical hybrid multilevel DC-AC converter," Proceedings of IEEE Energy Conversion Congress and Exposition, pp. 4012-4019, 2010.

[16] Y. Liao and C. Lai, "Newly-Constructed Simplified Single-Phase Multistring Multilevel Inverter Topology for Distributed Energy Resources," IEEE Transactions on Power Electronics, vol. 26, pp. 2386-2392, 2011.

Simplified five-level voltage source inverter with level-phase-shifted carriers based modulation... (Suroso) 
[17] K. K. Gupta and S. Jain, "Comprehensive review of a recently proposed multilevel inverter," IET Power Electronics, vol. 7, pp. 467-479, 2014.

[18] Suroso, A. Mubyarto and T. Noguchi, "A Different Single-Phase Hybrid Five-Level Voltage-Source Inverter Using DC-Voltage Modules," TELKOMNIKA Telecommunication, Computing, Electronics and Control, vol. 12, pp. 557$562,2014$.

[19] Suroso, A. N. Azis and T. Noguchi, "Five-level PWM inverter with A Single DC Power Source for DC-AC Power Conversion," International Journal of Power Electronics and Drive System, vol. 8, pp.1212-1219, 2017.

[20] G. C. Raj, M. Kaliamoorthy, V. Rajasekaran and R. M. Sekar, "Single-Phase Cascaded Grid Connected Multilevel Inverter for Interfacing Renewable Energy Sources With Microgrid," Journal of Solar Energy Engineering, vol. 137, pp. 1-10, 2014.

[21] D. Karthikeyan, R. Palanisamy, K. Vijayakumar, A. Velu and D. Selvabharathi, "Parallel Connected VSI Inverter Using Multi-Carrier Based Sinusoidal PWM Technique," TELKOMNIKA Telecommunication, Computing, Electronics and Control, vol. 15, pp. 1625-1631, 2017.

[22] Suroso, and A. N. Aziz, "Voltage balancing circuits for five-level power inverter with a single DC voltage source", 3rd International Conference on Information Technology, Computer, and Electrical Engineering (ICITACEE), pp.147-150, 2016.

\section{BIOGRAPHIES OF AUTHORS}

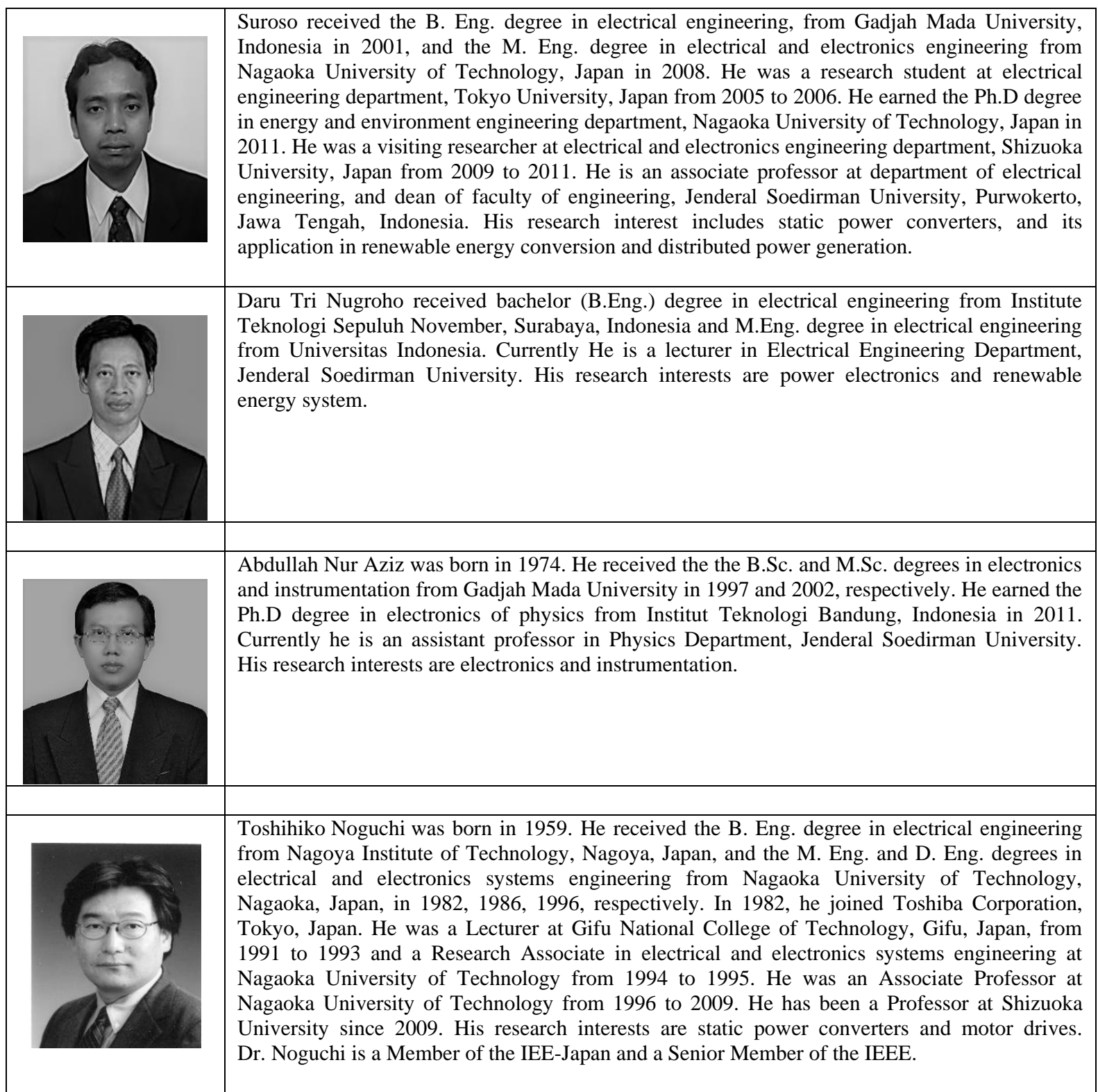

